\title{
Development of e-Book As A Teaching Material In Anatomy Physiology Course
}

\author{
Desy Afyanti Lubis ${ }^{1 *}$, Marnala Tobing ${ }^{1}$, Dian Mayasari ${ }^{1}$, Lina Pangaribuan ${ }^{1}$, Siti Wahidah ${ }^{1}$ \\ \{*avriandesy8@gmail.com\} \\ Department of Family Walfare Education, Faculty of Engineering, Medan State University, Medan, \\ Indonesia $^{1}$
}

\begin{abstract}
This study had aims: to determine the effect of e-books on the students learning outcomes in Anatomy and Physiology of Beauty course; to improve the knowledge of the students in Anatomy and Physiology of Beauty course; to improve the competence of the students in Anatomy and Physiology of Beauty practical. The type of the research used in this study is Research and Development (R \& D) by using the stages or procedures that have been adapted, such as: Needs analysis; develop the products; validation and revision; small group trials; medium group trials; large groups trials; final product. The subjects of these research trials are 30 students in first semester of Beauty Education in State University of Medan (UNIMED), which were tested on 3 small group students, 9 middle group students and 30 large group students. The expert validation consists of 1 media expert and 2 material experts. The instruments for collecting the data used in this study are using the questionnaires and tests; validator questionnaire and effectiveness questionnaire include the rating scale and techniques analysis the data using a Likert scale. The research results of media expert which took a percentage of $88.56 \%$ obtained the "very good" criteria and research result of material experts which took a percentage of $90.5 \%$ obtained the "very good" criteria; secondly, the results of small group trials expert which took a percentage of $67.7 \%$, obtained the "Good" criteria, the medium group trial which took a percentage of $80.33 \%$ obtained the "Good" criteria and the large group trial which took a percentage of $90.17 \%$ obtained the "Very Good" criteria; thirdly, the trial of effectiveness of students which took a percentage of $91 \%$ obtained the "Very Good" criteria. Thus, the development of E-book as a teaching material in Anatomy and Physiology of Beauty course is considered effective and feasible to be used as a learning media.
\end{abstract}

Keywords: Development of e-Book, anatomy, physiology, beauty material, skin and hair material.

\section{Introduction}

The Act No. 20 of 2003 on National Education System concerning the National Education System, section 1 of article 1 mention that education is a conscious and planned effort to realize a learning atmosphere and learning process so that students actively develop their potential to have religious spiritual strength, self-control, personality, intelligence, noble character, and skills needed by himself, society, nation and state. Based on this, it seems that what will be developed is the potential of beauty education students; they are human resources that are very important for the development and growth of a nation and state. Therefore, improving the quality of national education needs to be pursued with the right programs. 
In generally, the problems above are faced by technology and vocational education institutions because technology as a studied object is a dynamic field (always developing) and have a part of global scope. Some of the courses taught are included in the technology field and have the global scope, including Anatomy and Physiology of Beauty.

The subject of Anatomy and Physiology of Beauty is closely related to the practice of the Hair and Skin Beauty Expert Package, such as hair care, styling, trimming, coloring, curling, straightening, smothing and rebonding, facial, makeup, hand and foot care and body care. Therefore, before doing skin care and hair styling there are initial steps that must be known by the students, which is about the knowledge of skin type and hair type, with the aim of determining the ingredients, cosmetics, techniques and treatments that are appropriate to the client's circumstances. To be able to carry out these activities, the students must be compotents in the subject matter of Anatomy and Physiology of Beauty.

This curriculum in this course is organized into 3 practice credits, where all the subjects given in the form of face to face during one semester are practicum activities. Whereas to fulfill the demands of the course in Anatomy and Physiology of Beauty is not enough to be obtained only through practical activities. Concretely this gap problem arises when several graduates are accepted to work in salons and open their own businesses. As according to the recognition of several alumni who are currently working in beauty salons and are engaged in makeup artists, it turns out that their academic abilities and skills are still not enough to carry out the job description. There are still many new things, especially regarding some skin care techniques and hairdressing that they haven't gotten in college so they still have to enrich their knowledge by digging it from outside academic sources, for example by taking courses, reading books and articles - articles in mass media, and internet use. From this it appears that although graduates are equipped with knowledge and skills from campus, in the end they are still required to study independently after entering the workforce. In connection with the excavation of knowledge outside academics, it can actually be done since the graduates are still attending lectures. There are several things that cause this activity not doing by the students. First, the lack of motivation and awareness from educators, so the students can't see the importance of the knowledge and information outside of academics. Second, both educators and students are not able to see the benefits or effects of non-academic learning for enriching lecture material. Knowledge acquisition outside of academics can be done by using the internet. The use of the internet for educational purposes that is increasingly widespread, especially in developed countries, is a fact that shows that with this media it is possible to conduct a more effective learning process. This happens because the characteristics and characteristics of the internet are quite typical, so that it is expected to be used as a learning resource as other sources have been used previously such as radio, television, Interactive CDROM and the others.

Non-academic learning methods that will be examined here are learning resources by internet. Based on the current data (2008), shows the utilization of internet in Indonesia is only around $3.6 \%$ of 100 people in Indonesia (www.google.com/public). This reality illustrates that the reach of internet technology is still very limited, both by number of users and by location. The Anatomy and Physiology of Beauty course is a practical course which has 3 practical credits. Practical courses or often called practicums are learning strategies or forms of teaching used to teach together psychomotor (skills), understanding (knowledge), and affective (attitude) using laboratory facilities (Zainuddin, 2005).

The success of educators in teaching is determined by many factors such as planning, teaching preparation, teaching models, teaching media, facilities and other infrastructure [1]. Variations and innovations can take the form of learning media that can foster learning media 
and crisis and independent habits that make cosmetology students more interested in attending courses. Learning media is used as a teaching aid. One of the learning media is e-book [2]. With use of this e-book learning media, it can help teachers to explaining the subject matter and make it easier to understand the material presented [3].

\section{Methodology}

This study uses Research and Development ( $R \& D$ ) methods. The R \& D method is a research method used to produce a specific product and test the feasibility of the product. R \& $\mathrm{D}$ is carried out through several stages. Each stage is an activity process that has the target to be produced. The subjects in this study is e-book learning media in Anatomy and Physiology of Beauty course. The object in this study is the Beauty Eduation students in third semester. According to Borg and Gall, the initial product trial can be done in 1 class with 30 respondents [4], while according to Sugiyono (2008), the instrument has been validated with judgment experts can be tested on 30 respondents [5]. Therefore, the respondents who will be used in the trial of e-book have been worthy are 30 people. The technique used in sampling is total sampling. From 1 class, there were 30 beauty education students. The procedure that was prepared is a procedure that has been adapted from the steps of development research, according to Sugiyono [6]. The steps of the research to find out the potential and the problems in the learning are conducted by: identify the potential and the problems. This stage begins with how to do an observation in the classroom by doing a survey to the lecturers on the subject matter that will be developed and analyzing the appropriate learning tools for the IQF, so that there will be no deviation between the material developed and the syllabus.

After observing the research, it will continue to the planning stage. Development of Basic Product In developing a product, there needs to be a validation process to find out which product will be developed is feasible or not for use. The media that has been created is then examined by material experts and media experts who aim to give points to the media product. The experts who will validate the media products are the experts in the field of measurement, which are the Lecturers of Education and the Lecturers of courses, and for material experts will be present the lectures experts of learning media. The beginning trial (in small group) intends to see whether there are deficiencies or weaknesses of media products before media products are used as learning media in the actual learning process. The beginning trial (in small group) will be done by 3 beauty education students. It has been explained above, from product trials that will be known the shortcomings of the media products that are made. From the results of the small group trial, the media will be revised before the next trial phase is carried out. Field trials (medium group) were conducted for 9 students. According to Sugiyono (2014) the selection of a simple trial group that uses the group members of each subject is between 9 to 20 students. Just like the small group trial, the 9 students were chosen by means of random sampling starting from the tudents who had high, medium and low abilities. The medium group trial was conducted to assess media products after being revised from the results of the previous beginning trials. Media Revision; from the results of the field trial (medium group) then revised is carried out in accordance with the results of the trial.

Field Test (large group) is a trial that is done the same as the previous trial. This field test is the final stage of a series of trials and as a testing stage after it is done to 30 beauty education students in third semester. Like the previous trial stages, the students will be given a questionnaire to assess the efficiency of the media created. 
The product trial aims to find out the improvement of students knowledge about physiology and beauty anatomy material after using e-book learning media. This trial was conducted by comparing the results of the students test scores before using the e-book learning media (test) and the results of the students' test scores after using the e-book learning media (test). After passing the field test, all the critics and suggestions from the media that have been made will be the material revised from the media. This media revision will determine the results of media products later. Implementation is to convey the results of products to users. After revising the field test phase, the media products can be produced and can be used as learning media in subjects of physiological and beauty anatomical continental food knowledge. The techniques for collecting the data in this study were conducted in four ways, such as the interviews, observation, questionnaires, and tests. The interviews used in this study were classified as free interviews. This interview is used to find out the needs analysis. Respondents in this interview were lecturers of courses. The observation method used in this study is open observation. The activity was done by the researcher is to obtain data about the circumstances / situations that exist when implementing learning. Observations in this study aim to observe and know the use of media, the use of teaching methods, and the attitudes of beauty education students in the learning process. This questionnaire is used to find out the results of validation or input on e-book learning media that has been generated. Validation was carried out by media expert lecturers, material expert lecturers, lecturers of courses.

Techniques for collecting the data in this study is about to reveal the data of physiological and beauty anatomy knowledge in Anatomy and Physiology of beauty before and after using e-book, namely by doing a pretest and posttest. The test used in this test is multiple choice with a total of 40 items. The instrument for collecting the data is in the form of a questionnaire on the quality of learning media and the suitability of the material. This assessment sheet is a check list adapted from the Belawati Tian instrument in his book Learning Media Development with further development by researchers. Data collection instruments in this study are: Product Development Assessment Sheet (Questionnaire). The use of questionnaire instruments in research and development of e-book 8 learning media by researchers is used to determine the feasibility of products that have been developed. The questionnaire is composed of two types of questionnaires, namely a questionnaire for product assessment by material experts and an assessment by media experts. Assessment criteria for each questionnaire.

Data from questionnaires for product feasibility tests (product validation) and analyzed using descriptive statistical analysis techniques. The analysis intended by descriptive statistical techniques, namely the researcher clearly illustrates the acquisition of data. Then the results of the analysis are used to revise the learning media products developed by researchers. The researcher explained the results of product development in the form of e-book interactive learning media, testing the level of validity and feasibility of the product to be implemented in a learning on continental food knowledge subjects. Analyzing data from questionnaires, do the following steps:

1. The questionnaire that has been filled out by the respondent is checked for completeness.

2. Quantifying statements by giving scores according to pre-determined weights.

3. Make data tabulation

4. Calculate the percentage of each sub variable with the formula as follows: Percentage:

$\frac{\text { Amount of Earnings Score }}{\text { Maximum Score Amount) }} \times 100 \%$ 
From the percentage obtained then transformed into the following table:

Table 1. Value Interval Assessment of Questionnaire Indicators for Each Item

\begin{tabular}{llc}
\hline No & Criteria & Score Range \\
\hline 1. & Very Good & $81 \%-100 \%$ \\
2. & Good & $61 \%-80 \%$ \\
3. & Enough & $41 \%-60 \%$ \\
4. & Not Good & $21 \%-40 \%$ \\
5. & Very Not Good & $0 \%-20 \%$
\end{tabular}

The minimum e-book learning media test data set at the Beauty Education Study Program is 75 so that cosmetology students are said to pass or complete if they have a minimum score of 75 ..

\section{Result and Discussion}

Development of e-book learning media on anatomical physiology and beauty material. Development research begins with needs analysis by observing and interviewing lecturer subjects. The activity of identifying needs is done by interviewing lecturers and observations in the learning process. The results of observations and interviews revealed that the limited instructional material is the absence of interactive learning media on anatomical physiology and beauty material so that there is a need for media as teaching materials and student learning media for cosmetology. In the learning process, lecturers in delivering material are not maximal, because of the limited media. Whereas according to cosmetology students, there are still difficulties in learning anatomical physiology and beauty material. The interactive media e-book on physiology and beauty anatomy contains material about starting from understanding, function, classification, and equipped with practice tests regarding anatomical physiology and beauty. If the media is packaged attractively, cosmetology students will be more motivated to learn it, besides that the media can also be used as a learning media that can be used for the teaching and learning process, especially independent learning.

This development research was carried out in a number of stages that Sugiono put forward which were simplified into seven stages, which included the analysis phase of student makeup requirements, product development stage, expert validation stage and revision, small group trial phase, group testing phase and stage large group trials.

On the results of the validation sheet assessed by media experts, media experts gave an 88 rating, $56 \%$ that the media is feasible because the display of good images, animations and sounds is good. Then the material expert gives a $90.5 \%$ assessment that the media is suitable to be used in the teaching and learning process because the material displayed on the learning media is in accordance with the KKNI syllabus.

On the results of the questionnaire trials a small group of cosmetology students gave an assessment of $67.7 \%$. The things that affect students' assessment of makeup on learning media when conducting small class trials are the lack of media from various aspects starting from design, feasibility of contents and packaging of the media itself includes 1) background design that is monotonous and uninteresting so that the writing material on media not clearly visible to cosmetology students, then an interesting and appropriate background improve-ment is carried out; 2) space or distance between words on the material that is not neat, so that the material on the media looks unbalanced, then needs to be improved on writing material; 3) 
backsound not appropriate for learning media because it can interfere with cosmetology students when receiving lessons, then backsounds are replaced in accordance with the media, namely learning; 4) lack of interactive buttons on the media that cause media to be uninteresting and interactive, then add interactive buttons to increase curiosity makeup student; 5) animation that looks plain and usually makes students make up for saturation with media, then there needs to be more varied animations; and 6) writing that is too small and the font causes the writing not to be seen remotely. Therefore it is necessary to improve the first trial according to the deficiencies when carrying out small class trials.

In the medium group trial cosmetology students gave an $80.33 \%$ assessment, experienced an increase from previous trials because there had been improvements based on deficiencies when conducting small class trials, but when conducting moderate class trials there were also some disadvantages of learning media namely: a non-uniform background makes some parts of the material cannot be clearly seen by cosmetology students and therefore there needs to be a background improvement, and 2) there is writing in a less neat table so that when students make reading make up the wrong meaning of the material.

Finally, a large group trial was conducted with the results of the evaluation of $90.17 \%$. Based on the results of the student assessment which refers to the assessment as written by Ridwan (2012) the media is feasible to use without revision. When viewed from the student assessment, makeup from the small, medium and large class trials has increased. This is influenced by media improvements both from material and media. Media validation and material validation examine the learning media, then the validator gives an assessment, comments and suggestions are in accordance with the deficiencies during the trial run. improvements related to aspects in the validation sheet starting from the contents of the material, background use, animation, backsound, use of button buttons, font size, font type, color usage, image quality, clarity of instructions, use of interactive buttons, sound quality and the order of presentation that requires improvement so that the products produced are truly feasible for learning activities based on the assessment of lecturers and cosmetology students.

This is in line with previous research conducted by Resti Nidia Ardiani, a student from State University of Medan, majoring in PKK with the title of developing interactive learning media based on adobe flash cs 6 on making and installing krah techniques on blouses in class XI, dressmaking, state SMK 3 Pematang Siantar, test results try the small group $76 \%$, the group test results are $79 \%$ and the large group test $90 \%$ are feasible in production as learning media and Research Fitria Muslimah entitled development of interactive video learning room service media governance subjects in SMK 1 Sewon shows that the results feasibility assessment by material experts $(93.18 \%)$ was categorized as very feasible, while the assessment by media experts $(94.40 \%)$ and assessment by cosmetology students $(80.81 \%)$ was categorized as appropriate to be used as learning media.

\section{Conclusion}

Based on the results of research development carried out and the discussion that has been described can be concluded in this research is development of e-book learning media. At this stage it was concluded that the developed e-book learning media belonged to the excellent category with a percentage of the overall media expert value of $88.56 \%$ and the overall assessment of the material experts $90.5 \%$, the results of the small group trial $67.7 \%$, medium 
group test results $80.33 \%$ and large group test $90.17 \%$ have been feasible in production as learning media.

Based on the discussion of the results of the study, the authors show some suggestions for improving and further research. It is expected that teaching and learning processes such as lectures that have been carried out in the learning process are assisted by learning using interactive multimedia-based learning media that can have a positive influence on students' interests, motivations and learning outcomes in anatomical physiology and beauty.

\section{Acknowledgements}

The author would like to thank to Department of Family Walfare Education, Faculty of Engineering, Medan State University.

\section{References}

[1] A. Arsyad, Media Pembelajaran. Jakarta: Rajagrafindo Persada, 2009.

[2] B. J. G. Holmes, E-learning Concept and Practice. London: Sage Publication, 2006.

[3] S. Muhammad, "Efektivitas Pembelajaran Media E-Learning Berbasis Web Dan Konvensional Terhadap Tingkat Keberhasilan Belajar Mahamahasiswa tata rias (Studi Kasus Mahamahasiswa tata rias Fakultas Ekonomi Universitas Bina Darma Palembang).," 2014.

[4] W. R. Borg and M. D. Gall, Research Education: an Instruction. New York: Longman Tnc, 1983.

[5] Sugiyono, Metode Penelitian Kuantitatif Kualitatif dan R \& D. Bandung: Alfabeta, 2008.

[6] Sugiyono, Metode Penelitian Kombinasi (Mixed Methods ). Bandung: Alfabeta, 2014. 